University of Nebraska - Lincoln

DigitalCommons@University of Nebraska - Lincoln

$5-23-2018$

\title{
Organochlorine Chemical Residues in Northern Cardinal (Cardinalis cardinalis) Eggs from Greater Washington, DC USA
}

Christopher J. Schmitt

Kathy E. Echols

Paul H. Peterman

Carl E. Orazio

K. Christiana Grim

See next page for additional authors

Follow this and additional works at: https://digitalcommons.unl.edu/usgsstaffpub

Part of the Geology Commons, Oceanography and Atmospheric Sciences and Meteorology Commons, Other Earth Sciences Commons, and the Other Environmental Sciences Commons

This Article is brought to you for free and open access by the US Geological Survey at DigitalCommons@University of Nebraska - Lincoln. It has been accepted for inclusion in USGS Staff -- Published Research by an authorized administrator of DigitalCommons@University of Nebraska - Lincoln. 


\section{Authors}

Christopher J. Schmitt, Kathy E. Echols, Paul H. Peterman, Carl E. Orazio, K. Christiana Grim, Shirlee Tan, Nora E. Diggs, and Peter P. Marra 


\title{
Organochlorine Chemical Residues in Northern Cardinal (Cardinalis cardinalis) Eggs from Greater Washington, DC USA
}

\author{
Christopher J. Schmitt ${ }^{1}$ (I) Kathy R. Echols ${ }^{1} \cdot$ Paul H. Peterman $^{1} \cdot$ Carl E. Orazio ${ }^{1} \cdot$ K. Christiana Grim ${ }^{2} \cdot$ Shirlee Tan $^{2,3}$. \\ Nora E. Diggs ${ }^{4} \cdot$ Peter P. Marra ${ }^{4}$
}

Received: 23 January 2018 / Accepted: 11 May 2018 / Published online: 23 May 2018

(c) This is a U.S. Government work and not under copyright protection in the US; foreign copyright protection may apply 2018

\begin{abstract}
Northern Cardinal eggs from six neighborhoods near Washington DC were analyzed for organochlorine pesticides and PCBs. All compounds were detected more frequently and at higher concentrations in more heavily urbanized neighborhoods. DDT (mostly as $p, p^{\prime}$-DDE) was detected in all neighborhoods. $p, p^{\prime}$-DDT was typically $0.5-16 \mathrm{ng} / \mathrm{g}(\mathrm{ww})$ in most suburban neighborhoods but was not detected $(<0.1 \mathrm{ng} / \mathrm{g})$ in more rural areas; however, $p, p^{\prime}$-DDT was $127-1130 \mathrm{ng} / \mathrm{g}$ in eggs from two suburban Maryland nests and comprised $65.7 \%$ of total $p, p^{\prime}$-DDT isomers in the most contaminated sample, indicating recent exposure to un-weathered DDT. Total chlordane (sum of 5 compounds) was $2-70 \mathrm{ng} / \mathrm{g}$; concentrations were greatest in older suburban neighborhoods. Total PCB (sum of detected congeners) was $<5-21 \mathrm{ng} / \mathrm{g}$. Congener patterns were similar in all neighborhoods and resembled those typical of weathered mixtures. Results indicate that wildlife remains exposed to low concentrations of legacy contaminants in suburban neighborhoods and that cardinal eggs can be used to monitor localized contamination.
\end{abstract}

Keywords Organochlorine pesticides $\cdot$ Polychlorinated biphenyls $\cdot$ Chlordane $\cdot$ Birds

The contamination of urban and suburban environments by industrial chemicals, consumer products, and pesticides is widely recognized. Anthropogenic chemicals were detected in $80 \%$ of 139 US streams draining urban, industrial, suburban, and agricultural areas (Kolpin et al. 2002), and polychlorinated biphenyls (PCBs) and pesticides were detected in streams of seven US metropolitan areas (Nowell et al. 2013). Birds inhabiting urbanized areas may be exposed to chemicals presently or formerly used in and around homes and other buildings, in transportation and utility corridors

Christopher J. Schmitt

cjschmitt@usgs.gov

1 Columbia Environmental Research Center, U.S. Geological Survey, 4200 New Haven Road, Columbia, MO 652011, USA

2 Center for Species Survival, Smithsonian National Zoological Park, Front Royal, VA, USA

3 Present Address: Public Health Seattle and King County, 401 5th Ave., Seattle, WA 98104, USA

4 Smithsonian Migratory Bird Center, National Zoological Park, 3001 Connecticut Avenue NW, Washington, DC 20008, USA (including spills), or released from landfills and hazardous waste sites. Persistent organic pollutants (POPs) typically associated with urban and suburban environments include legacy organochlorine pesticides (OCPs) and PCBs, which are ubiquitous, bioaccumulative pollutants that are toxic to many species (Darnerud 2003; Chen et al. 2010; Beyer and Meador 2011).

Although most OCPs are no longer used and PCBs are not manufactured, large quantities of these compounds persist in many places as a result of historical use and disposal, especially near former sites of synthesis, formulation, and storage (e.g., Secord et al. 1999; Hinck et al. 2009; Bienkowski 2014; Mackintosh et al. 2016). OCPs were widely used in the United States to control insects in agriculture, forests, wetlands, and suburban neighborhoods and are present in and around homes (Bekarian et al. 2006; Stapleton et al. 2005). Suburban DDT uses in the United States from 1939 to 1972 included mosquito fogging of neighborhoods and spraying to control insects on fruit and ornamental trees (USEPA 2018a). Chlordane was incorporated into soils around buildings for ant and termite control from 1948 until its use was restricted in 1988 (ATSDR 1994). PCBs were used in many applications including dielectric 
fluids, plasticizers, and lubricating and cutting oils (USEPA 2018b). Masonry and concrete buildings erected from the 1940s through the 1970s commonly had PCBs in paints (at 5\%-10\% concentration) and in caulks and adhesives (10\%-20\%; e.g., Priha et al. 2005). PCBs also were used in home electrical equipment, including the ballasts of fluorescent light fixtures (USEPA 2018b).

Comparatively little is known about the health or longterm survival of birds residing in urban and suburban areas, where they are exposed to a wide variety of potentially harmful anthropogenic contaminants. To date, lead from gasoline combustion has been the primary focus of most studies investigating the effects of urban pollution on birds (e.g., Roux and Marra 2007; Scheifler et al. 2006). Studies of organic chemicals in birds inhabiting urban areas have mainly been focused on larger, upper trophic level species (e.g., Chen et al. 2010; Gao et al. 2009; Elliott et al. 2015). Studies completed in Europe, India, and South Africa have documented organohalogen concentrations in the eggs of several resident passerine species (Bouwman et al. 2013 and references therein), and European Starling (Sturnus vulgaris) eggs have been proposed for international monitoring (Eens et al. 2013). Eens et al. (2013) sampled starlings at one site in Illinois, but studies of organic chemicals in the eggs of North American passerine birds have mainly focused on releases from hazardous waste sites and pesticides in agricultural areas, and most have been conducted in wetlands and riparian corridors (e.g., Bishop et al. 1995; Hebert et al. 1994; Harris et al. 2000; Reynolds et al. 2001; Secord et al. 1999; Echols et al. 2004). Exposure of passerine birds inhabiting urban and suburban areas of the United States to bioaccumulative organic chemicals has received less study, and exposure to contemporary concentrations is unknown.

The Northern Cardinal (Cardinalis cardinalis; henceforth cardinal) is a non-migratory species indigenous to most of eastern and central North America. Cardinals commonly inhabit urban and suburban areas, where they forage primarily on fruits and seeds augmented with insects and other invertebrates during the spring-summer nesting season. Their diet may include sunflower and other seeds from bird feeders. Pairs establish and defend relatively small (0.21-2.60 ha) home ranges during the nesting season but may forage over several kilometers during the winter (Halkin and Linville 1999). Contaminant exposure of cardinals can therefore be considered localized compared to wider-ranging species.

In this paper we report the concentrations of OCPs, PCBs, and several other chlorinated industrial compounds in cardinal eggs collected from nests in the greater Washington, DC, USA (WDC) area. The study was conducted as a pilot for future avian monitoring of urban and suburban neighborhoods. Objectives were to document contemporary exposure and accumulation of selected POPs by birds residing in such areas and to establish a benchmark against which to compare future data. A secondary objective was to document lipid content, wet egg mass, and egg length and width as potential indicators of biological effects of chemical exposure.

\section{Materials and Methods}

Cardinal eggs were collected in May 2008 from 31 nests located within 6 neighborhoods in greater WDC chosen to represent a gradient of urbanization and population density (Fig. 1). The neighborhoods were located in Arlington, VA (AR, densely populated suburban); Takoma Park, MD (TP, densely populated suburban); Greenbelt, MD (GB, managed suburban); Dunkirk, MD (DK, suburban); West Friendship, MD (WF, rural suburban); and White Hall, MD (WH, rural). Within each neighborhood, 5 or 6 first-brood nests separated by at least $100 \mathrm{~m}$ were located and checked every $2-3$ days. One recently laid egg with intact shell was collected from each nest and transported to the laboratory on ice in clean, labeled containers. Fresh egg length, width, and mass were measured and the egg contents were dispensed into chemically cleaned, tared jars (I-CHEM $\left.{ }^{\circledR} 340-0120\right)$ and confirmed to be in an early developmental stage (i.e., no visible embryo). All samples were immediately chilled $\left(0{ }^{\circ} \mathrm{C}\right)$, shipped overnight on ice to the analytical laboratory, and stored frozen $\left(-16^{\circ} \mathrm{C}\right)$ until thawed for analysis.

A 1-g aliquot of each egg sample was extracted with a pressurized liquid extraction system (Dionex ASE 200; Echols et al. 2013). A 0.1 g-equivalent portion of the extract was removed for gravimetric lipid determination. Post-extraction

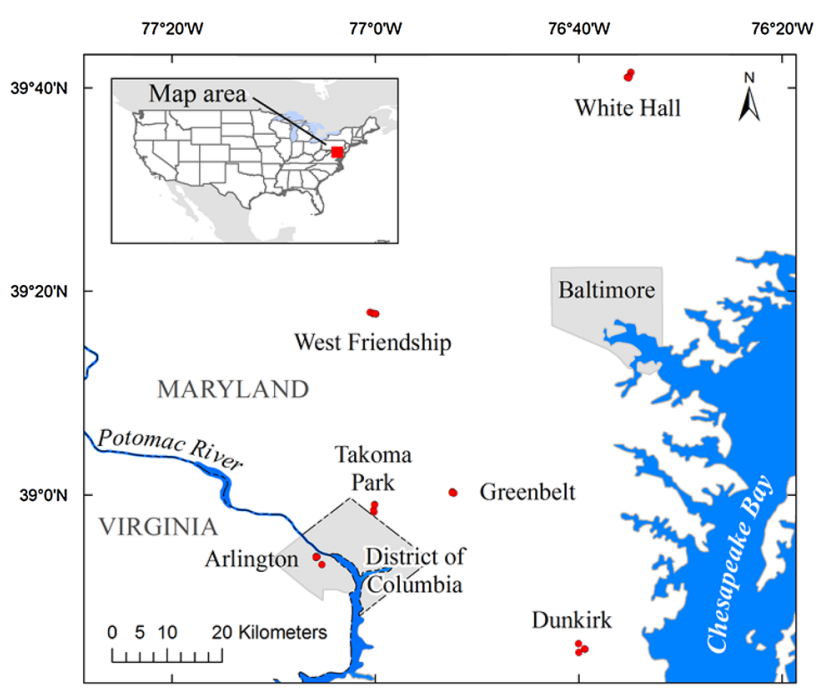

Fig. 1 Map of greater Washington, DC, USA showing the locations of sampled nests (red symbols) in Arlington, VA $(n=6)$, and Takoma Park, Greenbelt, Dunkirk, West Friendship, and White Hall (all MD, $n=5)$ 
cleanup included flash gel permeation chromatography and fractionation with flash alumina chromatography (Peterman et al. 2006, 2009). PCB congeners $(n=141)$ and the least polar OCPs were analyzed with a gas chromatography/quadrupole mass spectrometry (GC/QMS) system with selected ion monitoring (SIM) and cool injection technique (Thermo Trace MS system). Limits-of-detection (LODs) were $0.3-5.5 \mathrm{ng} / \mathrm{g}$ wet-weight (ww) for PCB congeners, $0.9 \mathrm{ng} / \mathrm{g}$ for hexachlorobenzene (HCB), and $1.0-3.1 \mathrm{ng} / \mathrm{g}$ for pentachlorobenzene, octachlorostyrene, heptachlor, $o, p^{\prime}$ DDE, $p, p^{\prime}$-DDE, $o, p^{\prime}$-DDT, and mirex. More polar OCPs (e.g., dieldrin, heptachlor epoxide) were analyzed by GC/ high-resolution (HR) MS (GC/HRMS; Waters Autospec M) with HRSIM (Echols et al. 2013). LODs were $0.2 \mathrm{ng} / \mathrm{g}$ for methoxychlor, $0.1 \mathrm{ng} / \mathrm{g}$ for $p, p^{\prime}$-DDT and $p, p^{\prime}$-DDD, and $0.01-0.10 \mathrm{ng} / \mathrm{g}$ for all other compounds. Quality assurance measures for all analyses included procedure blanks and fortified egg matrices. All samples contained method surrogate quantification standards. Recoveries were considered acceptable for all analyses and were typically $40 \%-110 \%$. Endosulfan- 1 and $\alpha$ - and $\gamma$-benzene hexachloride (BHC) were not quantified due to low recovery. Analytical results are reported in ng/g wet-weight (ww) and were not corrected for recovery. Chemical identities, additional information about analytical methods, QA, and LODs for all analytes are available online (Schmitt et al. 2018) along with raw data for detected compounds and lipid content; shell thickness; and fresh egg length, width, and mass for each sample.

Statistical analyses were conducted with V. 9.4 of the Statistical Analysis System (SAS Institute, Cary, NC). For residue concentrations that were $>$ LOD in $>75 \%$ of the samples (few), $50 \%$ of the LOD was substituted for censored values and in OCP group totals. Total PCB and chlordane concentrations are reported and were analyzed as the sum of detected congeners. Differences among neighborhoods were analyzed with the nonparametric Kruskal-Wallis test and Dwass, Steel, Critchlow-Fligner post-hoc comparisons (SAS PROC NPAR1WAY) because most variables failed to meet the distributional and other assumptions of parametric methods. A p-value of $<0.05$ was used to judge the significance of all statistical tests unless otherwise indicated.

\section{Results and Discussion}

Among the biological variables, only lipid content differed significantly among neighborhoods $(\mathrm{p}=0.044)$. Mean lipid content was 5.8\%-5.9\% in eggs from AR and TP, the two most urbanized areas, and 8.2\%-8.8\% elsewhere. Lipid differences may reflect nutritional status/diet quality of the nesting females or egg age (Rattner et al. 2016); however, the latter is unlikely considering that all eggs were in early developmental stages. Among-neighborhood differences for fresh egg mass, egg length, and egg width were not significant $(\mathrm{p}=0.16-0.96)$.

Concentrations of most residues generally were greatest in neighborhoods near WDC (TP, GB, and AR) and smallest in more rural neighborhoods. Residues of DDT (mostly as $p, p^{\prime}$-DDE) were detected $(>0.2 \mathrm{ng} / \mathrm{g})$ in eggs from 26 of 31 nests $(84 \%) ; p, p^{\prime}$-DDT and $p, p^{\prime}$-DDD were detected $(>0.1 \mathrm{ng} / \mathrm{g}$ ) less frequently (55\% and $29 \%$, respectively). Total DDT (sum of $p, p^{\prime}$-isomers) and $p, p^{\prime}$-DDE differed significantly among neighborhoods $(\mathrm{p}=0.028-0.036)$. Concentrations were greatest in GB and TP, but concentrations and isomer profiles varied greatly within and among neighborhoods (Fig. 2A). The $p, p^{\prime}$-isomer composition was $>87 \%$ $p, p^{\prime}$-DDE in most samples with detectable $p, p^{\prime}$-DDT and $p, p^{\prime}$-DDE, with two notable exceptions: The egg from TP Nest 100 contained $715 \mathrm{ng} / \mathrm{g}$ of total $p, p^{\prime}$-DDT isomers comprising $76.5 \% p, p^{\prime}$-DDE and $127 \mathrm{ng} / \mathrm{g}$ of $p, p^{\prime}$-DDT (17.8\%); and GB Nest 49 contained $1719 \mathrm{ng} / \mathrm{g}$ of total $p, p^{\prime}$-isomers comprising only $32.2 \% p$, $p^{\prime}$-DDE (Fig. $2 \mathrm{~A}$ ). This sample contained $1130 \mathrm{ng} / \mathrm{g}$ of $p, p^{\prime}$-DDT (65.7\%), which was confirmed by full-scan GC/QMS (Fig. 3). Total $p, p^{\prime}$-isomer concentrations were lower $(2.2-29.2 \mathrm{ng} / \mathrm{g})$ in other samples with proportionally high concentrations of $p, p^{\prime}$-DDT (Fig. 2A). $o, p^{\prime}$-DDT, an impurity of technical DDT, was detected in two samples: TP Nest 100 contained $2.8 \mathrm{ng} / \mathrm{g}$ of $o, p^{\prime}$-DDT, which is consistent with its $715 \mathrm{ng} / \mathrm{g}$ total $p, p^{\prime}$-isomer concentration (Fig. 2A). In contrast, the egg from DK Nest 40 contained $21.7 \mathrm{ng} / \mathrm{g}$ of $o, p^{\prime}$-DDT but did not contain high concentrations of any other analytes. The identity of this residue is uncertain because it was not confirmed by fullscan GC/QMS.

Technical DDT comprises 65\%-80\% p,p'-DDT, which is rapidly metabolized to $p, p^{\prime}$-DDE by birds. Consequently, $p, p^{\prime}$-DDE is typically the most abundant DDT homolog in bird eggs (Blus 2011 and references therein). As such, the presence of proportionally high concentrations of $p, p^{\prime}-$ DDT indicates relatively recent exposure of animals to DDT (Aguilar 1984). Although insecticidal use of DDT in the United States has been restricted since 1974, the GB and TP homolog mixtures indicate recent exposure to un-weathered DDT. Potential sources of technical DDT (and hence $p, p^{\prime}-$ DDT) include illicit use (including pesticide treatment of birdseed) or containers stored outdoors or in outbuildings. The latter could contaminate co-located bird seed or insects eaten by the cardinals. Residual DDT from historical use is unlikely given the proportionally high $p, p^{\prime}$-DDT concentrations. We also note that GB and TP are near a hazardous waste site where elevated concentrations of DDT, other pesticides, and PCBs have been reported (USEPA 2017).

Eggshell thinning and reproductive effects in birds have been attributed to $p, p^{\prime}$-DDE (Blus et al. 1997). In the field and laboratory studies reviewed by Blus (2011), the smallest effect concentrations were 1-2 $\mu \mathrm{g} / \mathrm{g}$ (1000-2000 ng/g ww), 

isomers (A) and cyclodiene pesticides (B) in Northern Cardinal eggs from greater Washington, DC, USA neighborhoods (censored values represented as $50 \%$ LOD)
Fig. 2 Concentrations of DDT

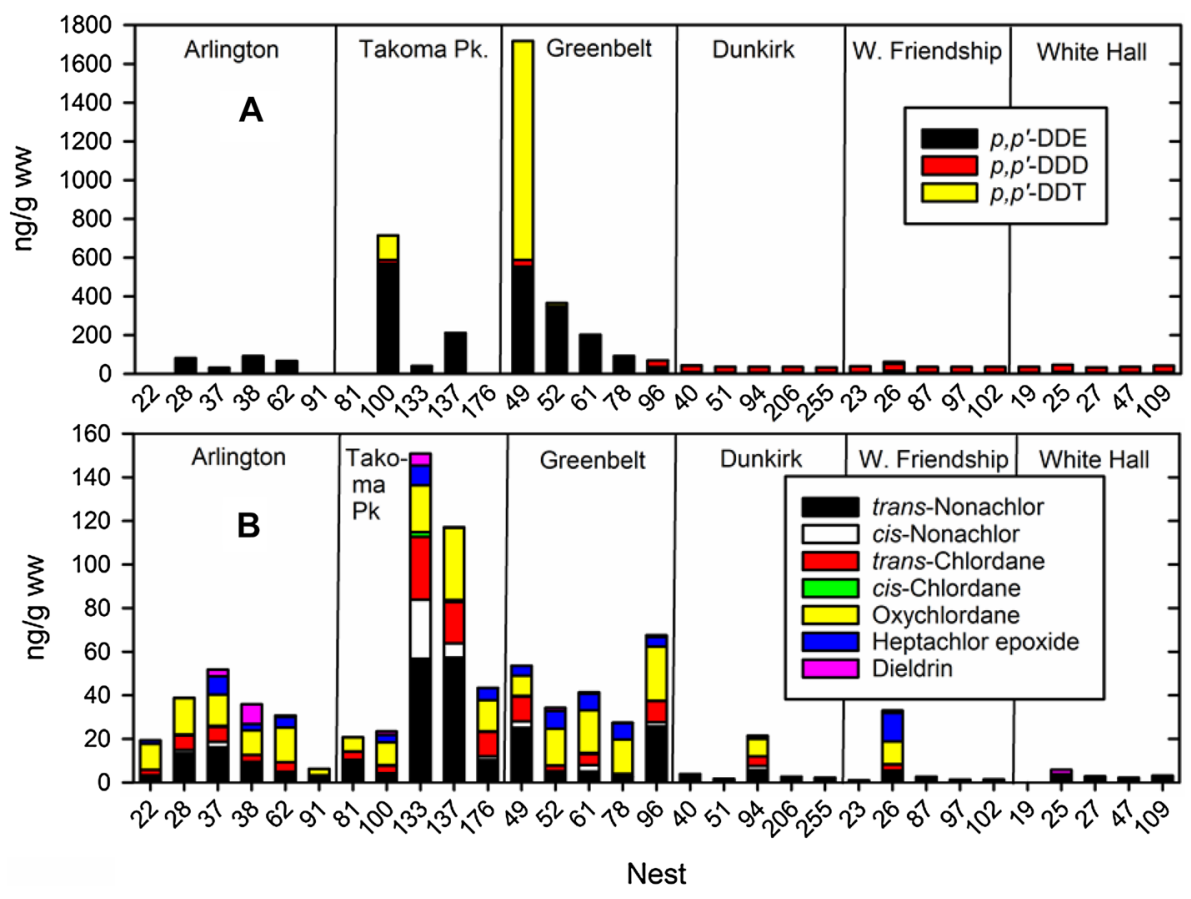

Fig. 3 Full-scan GC/QMS mass spectrum of compounds detected in the alumina fraction from Greenbelt Nest 49, which was a near-perfect match to a $p, p^{\prime}$-DDT standard

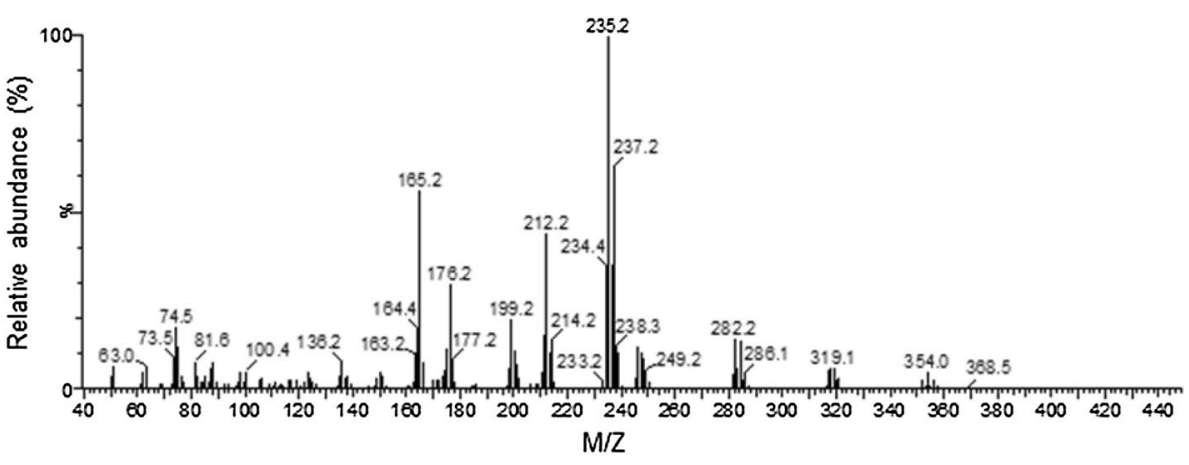

but they varied by more than 10-fold among species and no passerine birds were evaluated. In our study, the greatest $p, p^{\prime}$-DDE concentration (589 ng/g ww) was less than known thresholds (Blus 2011). Nevertheless, $p, p^{\prime}$-DDE would have been $1720 \mathrm{ng} / \mathrm{g}$ ww if all the $p, p^{\prime}$-DDT the GB egg had been metabolized to $p, p^{\prime}$-DDE, which would exceed the lowest thresholds in species evaluated by Blus (2011). In addition, the residues in these eggs, together with those of related compounds not included in our analyses, could also be toxic to birds through mechanisms other than eggshell thinning (e.g., Mackintosh et al. 2016).

Cyclodiene pesticides were detected in all 31 samples (Fig. 2B). Total chlordane (sum of cis- and trans-chlordanes and nonachlors, oxychlordane, and heptachlor epoxide) differed significantly among neighborhoods $(\mathrm{p}=0.001)$, as did concentrations of all components $(p<0.001-0.002)$ except heptachlor epoxide $(\mathrm{p}=0.093)$. No un-metabolized heptachlor was detected. Although there were exceptions, total chlordane and all components were greatest in the urbanized neighborhoods near WDC (AR, TP, and GB; Fig. 2B). Most total chlordane concentrations were $<2.0 \mathrm{ng} / \mathrm{g}$; however, TP Nests 133 contained 143 ng/g and Nest 137 contained $117 \mathrm{ng} / \mathrm{g}$. Oxychlordane, a metabolite of cis-chlordane (the primary active insecticide in technical chlordane), was detected in all samples; cis-chlordane was detected in 25 samples (80.6\%). trans-Chlordane and -nonachlor were also detected in all samples. Aldrin was not analyzed because it is rapidly metabolized (to dieldrin) and is seldom detected in vertebrates, but dieldrin was detected in 15 samples (48\%) and in at least one sample from all neighborhoods. Most dieldrin concentrations were $<2.0 \mathrm{ng} / \mathrm{g}$ but were $9.1 \mathrm{ng} / \mathrm{g}$ in AR Nest 38 and $5.5 \mathrm{ng} / \mathrm{g}$ ww in TP Nest 133. This sample also contained the greatest total chlordane concentration (Fig. 2B). Traces of endrin $(0.1 \mathrm{ng} / \mathrm{g})$ were detected in one DK sample.

Chlordane, heptachlor, and aldrin/dieldrin were used to control ants and termites in and around buildings and in agriculture to control soil insects. Heptachlor is also a 
minor component of technical chlordane. The residue patterns reflect residential uses; concentrations were generally greatest in densely populated neighborhoods located nearest to WDC. The profiles were dominated by longer-lived components and metabolites (e.g., oxychlordane and nonachlors; Fig. 2B). The presence of cyclodiene residues in less densely populated neighborhoods could also reflect recent urbanization of agricultural areas.

Cyclodiene insecticides (especially endrin, dieldrin, and oxychlordane) are highly toxic to birds (Elliott and Bishop 2011). Because they are neurotoxins, many toxicity thresholds for OCP residues are based on brain concentrations; there is comparatively little information about toxic effects associated with residues in eggs for many compounds, especially in passerine species. An additive model of pesticide toxicity ("dieldrin equivalents") for cyclodiene pesticides and DDT has been proposed (Elliott and Bishop 2011). Using the equivalency factors of this model and a brain:egg ratio of 0.27 [based on data from gulls (Vermeer and Reynolds 1970)], the maximum estimated dieldrin-equivalent concentrations in cardinal brains were $20.3-30.7 \mathrm{ng} / \mathrm{g}$ $(0.020-0.031 \mu \mathrm{g} / \mathrm{g})$, which are two orders of magnitude lower than the lethal brain concentrations in the studies reviewed by Elliott and Bishop (2011). However, the authors caution that the brain:egg conversion factors and the additive model are based on data from few species, and that these compounds may be toxic to birds via other mechanisms (e.g., Mackintosh et al. 2016).

Traces of mirex, which was formerly used as a flame retardant and as a soil insecticide, were detected $(>2.0 \mathrm{ng} / \mathrm{g})$ in 11 samples (36\%) and in at least one sample from all neighborhoods at $2.1-2.6 \mathrm{ng} / \mathrm{g}$. Other compounds detected at low concentrations included pentachloroanisole, a metabolite of the wood preservative pentachlorophenol $(n=8)$; the herbicide Dacthal $\odot(n=1)$; and the insecticide $\beta$-BHC, the most persistent BHC isomer (Gao et al. 2009). Endosulfan (-2 and sulfate), $\delta$-BHC, pentachlorobenzene, hexachlorobenzene, and octachlorostyrene were not detected in any samples.
At least one PCB congener was detected in 24 of 31 samples $(77 \%)$, but no sample contained more than 17 chromatographic peaks (Fig. 4). Concentrations were greatest in neighborhoods near WDC (AR, TP, and GB) and smallest in more rural neighborhoods (Fig. 4), and all samples with no detections were from the more rural neighborhoods (three each from WH and WF, one from DK). Of the 122 chromatographic peaks representing 141 PCB congeners included in our analysis, only 25 peaks representing 31 congeners exceeded LODs $(0.6-1.3 \mathrm{ng} / \mathrm{g})$. No congeners containing fewer than five chlorines were detected in any sample. The most frequently detected congeners were PCBs $153 / 132$ (71\%), 187 (68\%), 118 (48\%), 138/158 (39\%), 180/193 (39\%), and 199 (22\%), which collectively accounted for $62 \%-100 \%$ of total detected PCBs in samples with at least one detected congener (Fig. 4). The number of detected congeners increased with total PCB concentrations, which ranged from < LOD to $43.6 \mathrm{ng} / \mathrm{g}$. Although total PCB concentrations varied substantially among nests, differences among neighborhoods were nevertheless significant $(p=0.001)$. Congeners detected at the greatest concentrations were PCBs 153/132 (13.4 ng/g), 138/158 (7.4 ng/g), $118(5.9 \mathrm{ng} / \mathrm{g}), 172(5.8 \mathrm{ng} / \mathrm{g})$ and 180/193 (5.8 ng/g ww). PCB $118\left(2,3^{\prime}, 4,4^{\prime}, 5\right.$-pentachlorobiphenyl) is one of only two dioxin-like congeners resolved by our analysis; it was detected in most samples from neighborhoods located near WDC (Fig. 4). The other was PCB 105 (2,3,3',4,4'-pentachlorobiphenyl), which was detected $(0.62-1.47 \mathrm{ng} / \mathrm{g})$ in two samples from GB. The largest concentration of PCB 105 occurred in the sample containing the greatest concentration of PCB $118(5.9 \mathrm{ng} / \mathrm{g})$. Together these concentrations represent the toxic equivalent of $0.21 \mathrm{pg} / \mathrm{g}$ (ww) of 2,3,7,8-tetrachlorodibenzo- $p$-dioxin based on consensus avian toxic equivalency factors (van den Berg et al. 1998), which is very low.

Overall, PCB concentrations were low and comprised recalcitrant congeners containing five or more chlorines. The profiles are typical of weathered PCBs in birds (Harris and Elliott 2011 and references therein; Maldinado et al. 2016), and the maximum total concentrations ( $46.3 \mathrm{ng} / \mathrm{g}$ )
Fig. 4 Numbers and concentrations of detected polychlorinated biphenyl congeners in Northern Cardinal eggs from greater Washington, DC, USA neighborhoods

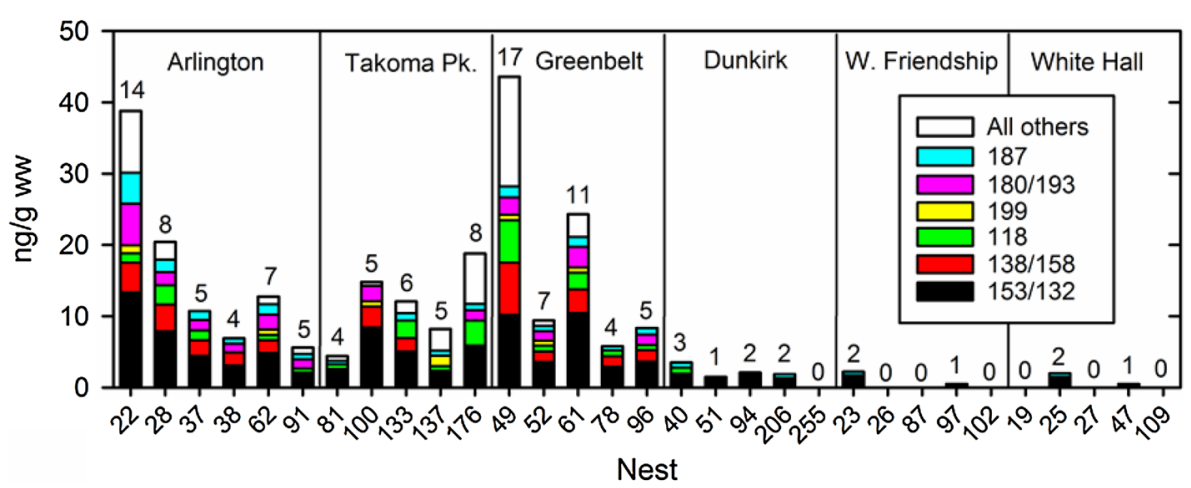


and dioxin-equivalent concentrations $(0.21 \mathrm{pg} / \mathrm{g})$ are less than known toxic thresholds for birds and concentrations in bird eggs from contaminated sites (Secord et al. 1999). However, we cannot discount the potential contribution of other unmeasured congeners or structurally similar compounds (e.g., chlorinated dioxins and furans) that may be present at very low concentrations. In addition, the consensus avian TEFs are dated, and more recent research has revealed substantial among-species differences in sensitivity to dioxinlike compounds (e.g., Farmahin et al. 2012; Hwang et al. 2016).

In summary, OCP and PCB concentrations were greater in cardinal eggs from urbanized areas near WDC than rural areas, but concentrations were generally low. These results are consistent with recent reports (Mora et al. 2016; Maldinado et al. 2016) indicating that concentrations of OCPs and PCBs in passerine and other resident and migratory birds have declined in recent decades. Nevertheless, concentrations were higher than most in some nests and the within-neighborhood variability was much greater than we expected, indicating that the neighborhoods and nearby areas are not uniformly contaminated. Samples with elevated concentrations of $p, p^{\prime}$-DDT were especially noteworthy in this regard. Within-clutch differences may contribute to this variation, but the differences are probably diet-related (Van den Steen et al. 2006). These localized differences, which no doubt reflect the cardinal's small home range and feeding site fidelity, support its use for spatial and geographic trend assessments and the identification of "hot spots". Concentrations may also be greater in species occupying higher trophic levels or that are more closely associated with soil. Our results and those of others (e.g., Bienkowski 2014) indicate that birds inhabiting these areas remain exposed to DDT and other POPs. Future studies might therefore consider measuring eggshell thickness.

Acknowledgements This study was jointly supported by the U.S. Geological Survey (USGS) and the Smithsonian Institution, the latter through a Smithsonian Endowment Grant to S. Tan and C. Grim. Collections were in accordance with US Fish and Wildlife Service permits under the auspices of the Neighborhood Nestwatch, a citizen-science program operated through the Smithsonian Migratory Bird Center at the National Zoo (http://www.sio.si.edu/Nestwatch), and were approved by the Institutional Animal Care and Use Committee of the Smithsonian National Zoological Park. M. Hooper and D. Tillitt (USGS) reviewed all or parts of earlier versions of the paper. K. Feltz (USGS) prepared the samples for analysis, C. Chojnacki (USGS) prepared the map, and R. Tillitt (USGS) compiled the data for release. Any use of trade, product, or firm names is for information purposes only and does not imply endorsement by the U.S. government.

\section{References}

Agency for Toxic Substances and Disease Registry (ATSDR) (1994) Toxicological profile for chlordane. U.S. Department of Health and Human Services, Public Health Service, Atlanta, GA

Aguilar A (1984) Relationships of DDE/DDT in marine mammals to the chronology of DDT input into the ecosystem. Can J Fish Aquat Sci 21:840-844

Bekarian N, Payne-Sturges D, Edmondson S, Chism B, Woodruff TJ (2006) Use of point-of-sale data to track usage patterns of residential pesticides: methodology development. Environ Health 5:15-26

Beyer WN, Meador JP (eds) (2011) Environmental contaminants in biota, 2nd edn. CRC Press, Boca Raton, FL

Bienkowski B (2014) DDT still killing birds in Michigan. Environ Health News July 28. https://www.scientificamerican.com/article/ ddt-still-killing-birds-in-michigan/. Accessed 11 Jun 2017

Bishop CA, Koster MD, Chek AA, Husssell DJT, Jock K (1995) Chlorinated hydrocarbons and mercury in sediments, red-winged blackbirds (Agelaius phoeniceus) and tree swallows (Tachycineta bicolor) from wetlands in the Great Lakes-St. Lawrence River basin. Environ Toxicol Chem 14:491-501

Blus LJ (2011) DDT, DDD, and DDT in birds. In: Beyer WN, Meador JP (eds) Environmental contaminants in biota, 2nd edn. CRC Press, Boca Raton, pp 425-444

Blus LJ, Wiemeyer SN, Bunck CM (1997) Clarification of effects of DDE on shell thickness, size, mass, and shape of avian eggs. Environ Pollut 95:67-74

Bouwman H, Viloen IM, Quinn LP, Polder A (2013) Halogenated pollutants in terrestrial and aquatic bird eggs: converging patterns of pollutant profiles, and impacts and risks from high levels. Environ Res 126:240-253

Chen D, Hale RC, Watts BD, La Guardia MJ, Harvey E, Mojica EK (2010) Species-specific accumulation of polybrominated diphenyl ether flame retardants in birds of prey from the Chesapeake Bay region, USA. Environ Pollut 158:1883-1889

Darnerud PO (2003) Toxic effects of brominated flame retardants in man and in wildlife. Environ Internat 29:841-853

Echols KR, Tillitt DE, Nichols JW, Secord AL, McCarty JP (2004) Accumulation of PCB congeners in nestling Tree Swallows (Tachycineta bicolor) on the Hudson River, New York. Environ Sci Technol 38:6240-6246

Echols KE, Peterman PH, Hinck JE, Orazio CE (2013) Polybrominated diphenyl ether metabolism in field collected fish from the Gila River, Arizona, USA-levels, possible sources, and patterns. Chemosphere 90:20-27

Eens M, Jaspers VLB, Van den Steen E, Bateson M, Carette C, Clergeau P, Cotantini D, Dolenec Z, Elliott JE, Flux J, Gwinner H, Halbrook RS, Heeb P, Mazgajski TD, Moksnes A, Polo V, Soler JJ, Sinclair R, Veiga JP, Williams TD, Covaci A, Pinxten R (2013) Can starling eggs be useful as a biomonitoring tool to study organohalogenated contaminants on a worldwide scale? Eviron Internat 51:141-149

Elliott JE, Bishop CA (2011) Cyclodiene and other organochlorine pesticides in birds. In: Beyer WN, Meador JP (eds) Environmental contaminants in biota, 2nd edn. CRC Press, Boca Raton, pp 447-475

Elliott JE, Brogan J, Lee SL, Drouillard KG, Elliott KH (2015) PBDEs and other POPs in urban birds of prey partly explained by trophic level and carbon source. Sci Tot Environ 524-525:157-165

Farmahin R, Wu D, Crump D, Herve JC', Jones SP, Hahn ME, Karchner SI, Giesy JP, Bursian SJ, Zwiernik J, Kennedy MJ SW (2012) Sequence and in vitro function of chicken, ring-necked pheasant, and Japanese quail AHR1 predict in vivo sensitivity to dioxins. Environ Sci Technol 46:2967-2975 
Gao F, Luo X-J, Yang Z-F, Wang X-M, Mai B-X (2009) Brominated flame retardants, polychlorinated biphenyls, and organochlorine pesticides in bird eggs from the Yellow River Delta, North China. Environ Sci Technol 43:6956-6962

Halkin SL, Linville SU (1999) Northern cardinal (Cardinal cardinalis). In: Poole A, Gill F (eds) The birds of North America, no. 440. Academy of Natural Sciences, Philadelphia, and American Ornithologists Union, Washington, DC

Harris ML, Elliott JE (2011) Effects of polychlorinated biphenyls, dibenzo- $p$-dioxins and dibnezofurans, and polybrominated diphenyl ethers in wild birds. In: Beyer WN, Meador JP (eds) Environmental contaminants in biota, 2nd edn. CRC Press, Boca Raton, pp 477-528

Harris ML, Wilson LK, Elliott JE, Bishop CA, Tomlin AD, Menning KV (2000) Transfer of DDT and metabolites from fruit orchard soils to American Robins (Turdus migratorius) twenty years after agricultural use of DDT in Canada. Arch Environ Contam Toxicol 39:205-220

Hebert CE, Weseloh DV, Kot L, Glooschenko V (1994) Organochlorine contaminants in a terrestrial foodweb on the Niagara Peninsula, Ontario, Canada 1987-89. Arch Environ Contam Toxicol 26:356-366

Hinck JE, Norstrom RJ, Orazio CE, Schmitt CJ, Tillitt DE (2009) Persistence of organochlorine chemical residues in fish from the Tombigbee River (Alabama, USA): continuing risk to wildlife from a former DDT manufacturing facility. Environ Pollut 157:1207-1219

Hwang JH, Park JY, Park HJ, Bak SM, Hirano M, Iwata H, Park YS, Kim EY (2016) Ecological factors drive natural selection pressure of avian aryl hydrocarbon receptor 1 genotypes. Sci Rep 6:27526

Kolpin DW, Furlong ET, Meyer MT, Thurman EM, Zaugg SD, Barber LB, Buxton HT (2002) Pharmaceuticals, hormones, and other organic wastewater contaminants in U.S. streams, 1999-2000: a national reconnaissance. Environ Sci Technol 36:1202-1211

Mackintosh SA, Dodder NG, Shaul NJ, Aluwihare LI, Maruya KA, Chivers SJ, Danil K, Weller DW, Hoh E (2016) Newly identified DDT-related compounds accumulating in Southern California bottlenose dolphins. Environ Sci Technol 50:12129-12137

Maldinado AR, Mora MA, Sericano JI (2016) Seasonal differences in contaminant accumulation in neotropical migrant and resident songbirds. Arch Environ Contam Toxicol 72:39-49

Mora MA, Durgin B, Hudson LB, Jones E (2016) Temporal and latiitudinal trends of p, $\mathrm{p}^{\prime}$-DDE in eggs and carcasses of North American birds from 1980 to 2015. Environ Toxicol Chem 35:1340-1348

Nowell LH, Moran PW, Gilliom RJ, Calhoun DL, Ingersoll CG, Kemble NE, Kuivila KM, Phillips PJ (2013) Contaminants in stream sediments from seven United States metropolitan areas: part I: distribution in relation to urbanization. Arch Environ Contam Toxicol 64:32-51

Peterman PH, Feltz KP, Orazio CE, Echols KR (2006) Basic alumina flash chromatographic separation of bulk ortho-PCBs from nonortho-PCBs, PBDEs, PCDFs, PCDDs, PCDTs, OCPs and PCTs. Organohalogen Compd 68:2458-2461

Peterman PH, Feltz KP, Echols KR, Orazio CE (2009) A miniaturized S-X3 flash GPC cleanup column. In: Pittsburgh Analytical Conference (PittCon) 2009, Chicago, IL
Priha E, Hellman S, Sorvari J (2005) PCB contamination from polysulphide sealants in residential areas-exposure and risk assessment. Chemosphere 59:537-543

Rattner BA, Wiemeyer SN, Blus LJ (2016) Retrospective: adjusting contaminant concentrations in bird eggs to account for moisture and lipid loss during their incubation. Bull Environ Contam Toxicol 97:2-3

Reynolds KD, Rainwater TR, Scollon EJ, Sathe SS, Adair BM, Dixon KR, Cobb GP, McMurry ST (2001) Accumulation of DDT and mercury in Prothonotary Warblers (Protonotaria citrea) foraging in a heterogeneously contaminated environment. Environ Toxicol Chem 20:2901-2909

Roux K, Marra PP (2007) The presence and impact of environmental lead in passerine birds along an urban to rural land-use gradient. Arch Environ Contam Toxicol 53:261-268

Scheifler R, Coeurdassier M, Morilhat C, Bernard N, Faivre B, Flicoteaux P, Giraudoux P, Noel M, Piotte P, Rieffel D, de Vaufleury A, Badot P-M (2006) Lead concentrations in feathers and blood of common blackbirds (Turdus merula) and in earthworms inhabiting unpolluted and moderately polluted urban areas. Sci Tot Environ 371:197-205

Schmitt CJ, Echols KR, Peterman PH, Orazio CE, Grim C, Tan S, Diggs NE, Marra PP (2018) Organochlorine chemicals in northern cardinal eggs from suburban. U.S. Geological Survey data release, Washington, DC. https://doi.org/10.5066/F76W999M

Secord AL, McCarty JP, Echols KR, Meadows JC, Gale RW, Tillitt DE (1999) Polychlorinated biphenyls and 2,3,7,8-tetrachlorodibenzo$p$-dioxin equivalents in tree swallows from the upper Hudson River, New York State. Environ Toxicol Chem 18:2519-2525

Stapleton HM, Dodder NG, Offenberg JH, Schantz MM, Wise SA (2005) Polybrominated diphenyl ethers in house dust and clothes dryer lint. Environ Sci Technol 39:925-931

U.S. Environmental Protection Agency (USEPA) (2017) Superfund site: Beltsville Agricultural Research Center (USDA), Beltsville, MD. https://www.cumulis.epa.gov/supercpad/cursites/csitinfo. cfm?id=0300415. Accessed 26 Sept 2017

U.S. Environmental Protection Agency (USEPA) (2018a) DDT-a brief history an statues. https://www.epa.gov/ingredients-used-pesti cide-products/ddt-brief-history-and-status. Accessed 03 Jul 2018

U.S. Environmental Protection Agency (USEPA) (2018b) Polychlorinated biphenyls. https://www.epa.gov/pcbs/learn-about-polychlori nated-biphenyls-pcbs. Accessed 03 Jul 2018

van den Berg M, Birnbaum L, Bosveld AT, Brunström B, Cook P, Feeley M, Giesy JP, Hanberg A, Hasegawa R, Kennedy SW, Kubiak T, Larsen JC, van Leeuwen FX, Liem AK, Nolt C, Peterson RE, Poellinger L, Safe S, Schrenk D, Tillitt D, Tysklind M, Younes M, Waern F, Zacharewski T (1998) Toxic equivalency factors (TEFs) for PCBs, PCDDs, PCDFs for humans and wildlife. Environ Health Perspect 106:775-792

Van den Steen E, Dauwe T, Covaci A, Jaspers VLB, Pinxten R, Eens $M$ (2006) Within- and among-clutch variation of organohalogenated contaminants in eggs of great tits (Parus major). Environ Pollut 144:355-359

Vermeer K, Reynolds LM (1970) Organochlorine residues in aquatic birds in the Canadian prairie provinces. Can Field Natur 84:117-130 